\title{
Translation Analysis of Circumstances in The Novel "The Old Man and The Sea" by Ernest Hemingway and Its Indonesian Translation by Yuni Kristianingsih
}

\author{
$1^{\text {st }}$ Tri Purwaningsih \\ Department of Linguistics, \\ Graduate Studies UNS \\ Surakarta, Indonesia \\ Tripurwaningsih28@yahoo.co
}

\author{
$2^{\text {nd }}$ Mangatur Nababan \\ Department of Linguistics, \\ Graduate Studies UNS \\ Surakarta, Indonesia \\ Amantaradja@yahoo.com
}

\author{
$3^{\text {rd }}$ Riyadi Santosa \\ Department of Linguistics, \\ Graduate Studies UNS \\ Surakarta, Indonesia \\ riyadisantosa@staff.uns.ac.id
}

$\mathrm{m}$

\begin{abstract}
Circumstance is one of the three components of transitivity process in Hallidayan's Systemic Functional Linguistics (SFL). The study aims at investigating the types of circumstances in the source text and how they are translated in the target language. Circumstance in the source language is not always transformed as it is in the target language. The writer wants to know the translation techniques used by the translator in this particular situation. This is a descriptive qualitative research. The data in this research are words, phrases and clauses containing a circumstantial element, especially those underwent circumstance category shift. This research employed content analysis and Focus Group Discussion as data collection method. The findings show that some circumstances in the source language are translated into other components of transitivy process like material process, relational process, and participants. In terms of translation techniques, modulation and deletion are dominantly used, followed by establisheed equivalence, explicitation, reduction, discursive creation, and literal translation.
\end{abstract}

Keywords: Circumstances, Translation Techniques.

\section{INTRODUCTION}

This study applied the theory of transititvity based on the Systemic Functional Linguistics approach proposed by Halliday. Halliday's transitivity process covers three components, namely: the process itself, participants in the process and Circumstances. The process deals with kind of event or state that is being described, while participants are the entities involved in the process like actor, sayer, senser, goal, carrier, etc . The last component is Circumstances associated with the process. It specifies when, how, where and why of the process.

The study on transitivity theory that has been conducted in the previous research, commonly focuses on the Process. Different from other components, the study on circumstances are still limited. Dealing with the translation study, the writer wants to know how the circumstances are translated in the target language, whether or not, the circumstance is transferred as it is in the target language.

Therefore, this research only focus on the circumstances which are not translated into circumstance in the target language. For example; circumstance in the source language but transformed into other components of transitivity like process or participants. Also, the study identifies the translation techniques used by the translator in translating the circumstances which underwent shift; what translation techniques are dominantly used.

Circumstances can be classified into 9 types with different sub categories of each type. They are circumstances of extent, location, manner, cause, contingency, accompaniment, role, matter and angle. Circumstance of extent consist of distance, duration and frequency. While circumstance of location can be categorized into time and place. Circumstane of manner has $4 \mathrm{sub}$ categories; means, quality, comparison and degree. Sub categories like reason, purpose, and behalf belongs to circumstance cause. While circumstance contingency consists of condition, concession, and defult. Commitative and additive sub categories belongs to circumstance of accompaniment. Circumstance role has two sub categories, they are guise and product. Circumstance angle has two sub categories, namely source and view point. And the last is circumstance of matter.

Only some of the circumstances appear in the novel. They are dominated by circumstance place, quality, and time, followed by commitative, means, and purpose. Some sub categoris like 
degree, frequency, reason, duration, comparison matter and behalf also exist but is small in number.

\section{METHODOLOGY}

This research is descriptive qualitative research that applies purposive sampling. The data used in this study are those undergo circumstance category shift. The primary data were words or phrases that contains a circumstancial element and was translated into other transitivity components.

In this research, the data were collected from the novel entitled The Old Man And The Sea and its indonesian version by Yuni Kristianingsih. The writer read the original novel of The Old Man And The Sea to find the element of circumstances. After that, the writer read the translation version to be compared to the original one in terms of the elements of circumstances. The next step is identifying which data underwent shift, and which data did not. Those which underwent shift, were then taken as data provision. The last step, together with the informants in the focus group discussion., was determining the translation techniques used by the writer.

\section{FINDING AND DISCUSSION}

The findings show that the circumstances in the source language are not always translated in the form of circumstances in the target language, but in different components of transitivity process like material process, relational process, and participants as ilustrated in the table below. Of 120 data, 57 data of circumstances are translated into into other transitivity components while 63 data are deleted.

Table 1 Circumstance Shift

\begin{tabular}{|l|l|l|l|}
\hline \multicolumn{3}{|c|}{ Circumtance to other transitivity components } \\
\hline $\begin{array}{l}\text { Circumstanc } \\
\text { e to process }\end{array}$ & $\begin{array}{l}\text { Number } \\
\text { of Data }\end{array}$ & $\begin{array}{l}\text { Circumstance } \\
\text { to participant }\end{array}$ & $\begin{array}{l}\text { Number } \\
\text { of Data }\end{array}$ \\
\hline $\begin{array}{l}\text { - Material } \\
\text { process }\end{array}$ & 20 Data & - actor & 1 Data \\
\hline $\begin{array}{l}\text { - Material } \\
\text { process with } \\
\text { range }\end{array}$ & 6 Data & - goal & 19 Data \\
\hline $\begin{array}{l}\text { - Relational } \\
\text { process }\end{array}$ & 9 Data & - carrier & 1 Data \\
\hline \multicolumn{2}{|c|}{} & - attribute & 1 Data \\
\hline Total data & 35 data & + & 22 data \\
\hline \multicolumn{2}{|l|}{} & Deleted & 63 data \\
\hline & & $\begin{array}{l}120 \\
\text { data }\end{array}$ \\
\hline
\end{tabular}

\subsection{Circumstance to Process}

1) Material Process

Example:

data no:

009/TOMATS/

ST: Then he flew around the old man's head and rested on the line where he was more comfortable.

TT: Kemudian dia terbang mengitari kepala si lelaki tua dan beristirahat di atas tali tempat dia merasa lebih nyaman.

The data no 009, around the old man's head isa circumstance of place,

But transformed into material process: mengitari which means go or fly around the man's head. The word go or fly refers to activity that is doing using physical action.

2) Material Process with range

Example:

Data no:

001/TOMATS/

ST: The sail was patched with flour sacksand, furled, it looked like the flag of permanent defeat.

TT: Layar itu telah bertambal karung-karung tepung dan dalam keadaan tergulung seperti itu tampak seperti bendera kekalahan abadi.

The phrase with flour sacks in the source language belongs to circumstance means, but in the target language it become range. Range is the extended form of the process it self.

3) Relational Process

Example:

Data no:

038/TOMATS/

ST:The land must make a different too, in the shape of the clouds.

TT: Tentu ada yang berubah juga di daratan, yakni bentuk awan.

In the shape of the clouds is circumstance of quality. It explains the way land is being different. That circumstance is translated into relational process; yakni bentuk awan which define the different happened in the land ( daratan ).

\subsubsection{Circumstance to Participant}

1) Actor

Example: 073/TOMATS/ 
ST: The fish righted himself and swam off again slowly with the great tail weaving in the air.

TT: Ikan itu meluruskan diri dan berenang menjauh lagi dengan tenang. Ekor besarnya bergelombang di udara.

The circumstance of means ( with the great tail ) in the source language, is translated into Actor ( ekor besarnya ) which appear in the first part of the clause and function as the participant in the clause.

2) Goal

Example: 109/TOMATS/

ST: The skiff was sailing well considering the handicaps and he steered with the tiller under his arm.

TT: Perahu berlayar dengan baik walaupun keadaannya tak wajar, dan dia mengepit kemudi di bawah lengannya.

In data no 109 , the phrase with the tiller under his arm is circumstance of quality, explaining how the old man steered the skiff. But in the source language, it becomes goal ( kemudi di bawah lengannya ) of the material process mengepit.

3) Carrier

Example: 058/TOMATS/

ST: "You did not do so badly for something worthless." He said to his left hand.

TT: "Luka-luka itu bukan untuk sesuatu yang tidak berguna," katanya kepada tangan kirinya.

"so badly" in the source language which belongs to circumstance of quality, is translated into "luka-luka" that appears in the beginning of the relational process, so that it becomes carrier.

4) Attribute

Example:

035/TOMATS/

ST: But he could not and it stayed at the hardness and water-drop shivering that preceded breaking.

TT: Tapi ternyata tidak, dan tali itu tetap tegang sekali seakan hampir putus.

The phrase at the hardness and water-drop shivering in the target language is a circumstance of quality, but transformed into tetap tegang which become an attribute in the relational process.

\subsection{Translation Techniques}

In this study, the writer uses the translation techniques proposed by Molina\&Albir. Of 18 translation techniques, 7 translation techniques used by the translator. They are modulation $48,15 \%$ (78 data), deletion 38,89\% (63 data), established equivalence $7,41 \%$ (12 data), explicitation $2,47 \%$ (4data), reduction $1,85 \%$ (3 data), discursive creation $0,62 \%$ ( 1 data), literal $0,62 \%$ ( 1 data), as ilustrated in this following figure.

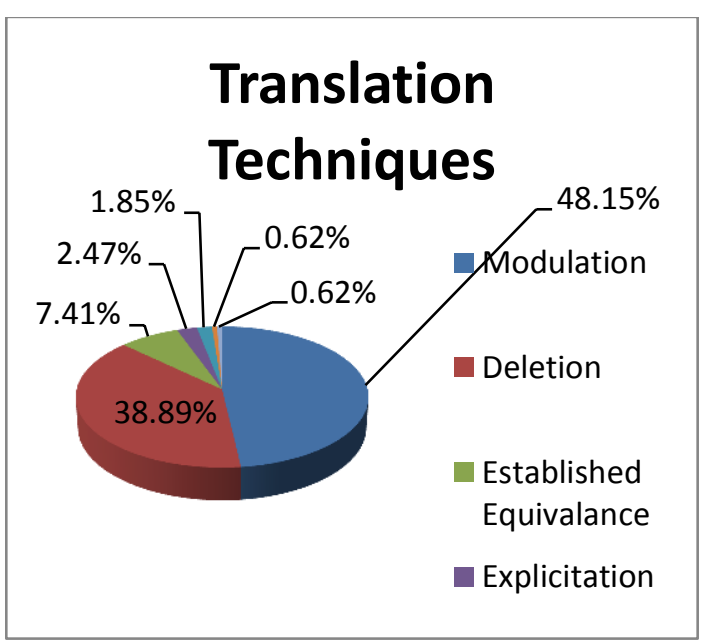

Figure 4: The percentage of translation techniques used by the translator.

\section{Modulation}

\begin{tabular}{|l|l|}
\multicolumn{2}{c}{ Table 2. Modulation } \\
\hline 008/TOMATS/ & $\begin{array}{l}\text { Anyway I feel better with the } \\
\text { sun and for once I do not } \\
\text { have to look into it. }\end{array}$ \\
\hline TT & $\begin{array}{l}\text { Bagaimanapun, aku merasa } \\
\text { lebih nyaman diterpa sinar } \\
\text { matahari asalkan aku tidak } \\
\text { menatap langsung ke arahnya. }\end{array}$ \\
\hline & \\
\hline
\end{tabular}

Modulation is translation technique in which the translator change his/her point of view. For exsmple from negative to positive, or from active to passive. In the data above, the source data tend to be active ( I feel better ) with the sun, but translated into passive; diterpa sinar matahari. 


\section{Deletion}

Table 3. Deletion

\begin{tabular}{|l|l|}
\hline 010/TOMATS & \multicolumn{2}{|l|}{} \\
\hline ST & $\begin{array}{l}\text { He felt the line carefully with } \\
\text { his right hand and noticed his } \\
\text { hand was bleeding. }\end{array}$ \\
\hline TT & $\begin{array}{l}\text { Dia memegang tali dengan } \\
\text { tangan kanannya dan } \\
\text { memperhatikan bahwa } \\
\text { tangannya berdarah. }\end{array}$ \\
\hline
\end{tabular}

In Deletion, words/phrase/clause in the source language is deleted by the translator. In the data no 010 , the word carefully does not appear in the target language because of being deleted by the translator.

\section{Established Equivalence}

Table 4. Established equivalance

\begin{tabular}{|l|l|}
\hline $\begin{array}{l}\text { 001/TO } \\
\text { MATS }\end{array}$ & $\begin{array}{l}\text { The sail was patched with flour } \\
\text { sacks and, furled, it looked like } \\
\text { the flag of permanent defeat. }\end{array}$ \\
\hline ST & $\begin{array}{l}\text { Layaritubertambalkarunggandum } \\
\text { dankalautergulung } \\
\text { tiangnampaksepertipanji- } \\
\text { panjitandatakhlukabadi. }\end{array}$ \\
\hline TT
\end{tabular}

Established equivalance technique belongs to the terms which are commonly used or familiar because they are just like what the dictionary define them as they are. The phrase with flour sacks in the source language is translated into karung gandum.

\section{Explicitation}

\begin{tabular}{|l|l|}
\multicolumn{2}{c|}{ Table 5. Explicitation } \\
\hline 030/TOMATS & $\begin{array}{l}\text { He settled comfortably against the } \\
\text { wood and took his suffering as it } \\
\text { came and the fish swam steadily } \\
\text { and the boat moved slowly } \\
\text { through the dark water. }\end{array}$ \\
\hline TT & $\begin{array}{l}\text { Dia bersandar dengan nyaman } \\
\text { pada kayu dan dia rasakan saja } \\
\text { penderitaannya sementara ikan itu } \\
\text { bergerak tenang dan perahu } \\
\text { bergerak pelan membelah air } \\
\text { yang kelam. }\end{array}$ \\
\hline
\end{tabular}

Explicitation is used to make the term clearer. It gives detail information about the term. The word membelah in the target text, make the through the dark water much easier to understand.

\section{Reduction}

Table 6. Reduction

\begin{tabular}{|l|l|}
\hline 013/TOMATS & $\begin{array}{l}\text { Holding the line with his left } \\
\text { shoulder again, and bracing on } \\
\text { his left hand and arm, he took } \\
\text { the tuna off the gaff hook and } \\
\text { put the gaff back in place. }\end{array}$ \\
\hline TT & $\begin{array}{l}\text { Dia memegang tali dengan bahu } \\
\text { kirinya lagi serta meguatkan } \\
\text { lengan kiri dan bahunya, lalu } \\
\text { mengambi tuna itu dengan } \\
\text { pangait tombak dan menaruh } \\
\text { tombak kembali ke tempatnya. }\end{array}$ \\
\hline
\end{tabular}

Different from deletion, in reduction technique, the translator only reduce some part of information and not delete all of them. In the data above, the translator reduce the preposition on in the source language.

\section{Discursive creation}

Table 7. Discursive creation

\begin{tabular}{|l|l|}
\hline 053/TOMATS & $\begin{array}{l}\text { He looked back at the } \\
\text { coils of line and they are } \\
\text { feeding smoothly. }\end{array}$ \\
\hline ST & $\begin{array}{l}\text { Dia melihat kembali } \\
\text { pada gulungan tali yang } \\
\text { tampak makin menipis. }\end{array}$ \\
\hline
\end{tabular}

Discursive creation refers to the translation of certain information in temporary basis, in the context given or particular situation. Usually it's a little bit free in the translation or beyond the context.

....They are feeding smoothly in the source language, is quite far from "yang tampak makin menipis" in the target language.

\section{Literal}

Table 8. Literal

\begin{tabular}{|l|l|}
\hline 104/TOMATS & $\begin{array}{l}\text { They had the scent and were } \\
\text { excited and in the stupidity of } \\
\text { their great hunger they were } \\
\text { losing and finding the scent in } \\
\text { their excitement. }\end{array}$ \\
\hline TT & $\begin{array}{l}\text { Mereka mencium bau amis dan } \\
\text { menjadi bersemangat Dan } \\
\text { dalam kebodohan karena } \\
\text { lapar yang sangat mereka } \\
\text { kehilangan buan itu. }\end{array}$ \\
\hline
\end{tabular}


Literal translation is known as word for word translation.

"dalam kebodohan karena lapar" in the target language is the word for word translation of "in the stupidity of their great hunger"

\section{IV.CONCLUSION}

Based on the explanation above, we can conclude that not all circumstances in the source text appeared in the form of circumstances in the target text. Some are transformed into other components of transitivity; process and transitivity, and some others are deleted by the translator.

The translation techniques used by the writer are dominated by modulation and deletion. It is influenced by the data used in this study which are those underwent shift in circumstance category.

The study on the transitivity commonly focuses on all three components of transitivity. Therefore, more research on circumstance are expected to be conducted at deeper level, especially in terms of its effect toward the translation quality.

\section{REFERENCES}

Blaxter, L., Hughes, C., and Thight, M. (2006).How to Research. England: Open University Press.

Pramudhaningrat, Yuni Kristianingsih.2009. LelakiTuadanLaut. Jakarta: PT. Serambi Ilmu Semesta.

Dornyei, Z. 2007. Research Methods in Applied Linguistics: Qualitative, Quantiative, and Mixed Methodologies. Oxford: Oxford University Press.

Halliday M.A.K. and Matthiessen, C.(2004). Functional grammar. London: Arnold.

Hemingway, Ernest. 1952. The Old Man And The Sea. New York: Scribner.

Lucia Molina \& Albi, A.H. (2002). Translation Techniques Revisited: A Dynamic and Functionalist Approach lucia molina and amparo hurtado albir. Meta: translators' Journal, XLVII(4), 498-512. Retrieved from http://id.erudit.org/iderudit/008033ar.

Santosa, Riyadi. (2003).SemiotikaSosial. Surabaya: Pustaka Eureka dan JP Press 